\title{
PENGARUH HUBUNGAN ANTAR MANUSIA DAN KONDISI \\ FISIK LINGKUNGAN TERHADAP KINERJA PEGAWAI \\ DALAM MANAJEMEN PSIKOLOGI
}

\author{
OLEH \\ SONIA AFRIANTI (17002104) \\ UNIVERSITAS NEGERI PADANG \\ EMAIL : \\ soniaafrianti04@gmail.com
}

\begin{abstract}
ABSTRAK
Dalam efektivitas penerapan (human relation) hubungan antar manusia dan kondisi fisik lingkungan terhadap kinerja. Kondisi fisik lingkungan merupakan lingkungan yang terbentuk dari penerapan hubungan antar manusia. Hubungan antar manusia mengandung arti suatu komunikasi karena sifatnya yang orientasi pada perilaku. Oleh sebab itu, organisasi selayaknya harus memberikan kebebasan bagi karyawan untuk berkomunikasi agar mereka mampu bekerjasama dengan baik dalam pekerjaan mereka. Hubungan antar manusia dan kondisi fisik lingkungan terhadap kinerja didalam sebuah teori yang menunjukkan adanya pengaruh secara positif dan signifikansi terhadap masing - masing kinerja.

Kata Kunci: Hubungan Antar Manusia, Kondisi Fisik Lingkungan, Kinerja, Komunikasi.
\end{abstract}

\section{A. PENDAHULUAN}

\section{Latar Belakang Masalah}


Dewasa ini perusahaaan atau organisasi semakin berorientasi pada pelanggan dan perubahan berskala besar. Perubahan besar itu akan selalu berkaitan dengan penentuan strategi. Salah satu strategi yang dapat ditempuh adalah dengan membentuk sumber daya manusia yang mampu bekerja secara bersama-sama selain itu perusahaan perlu memberikan kondisi lingkungan yang membuat karyawan nyaman bekerja sehingga menciptakan suatu kelompok kerja yang solid dimana pada akhirnya akan membentuk sikap serta perilaku karyawan sesuai dengan visi misidari organisasi atau perusahaan untuk mencapai tujuannya.

Kinerja merupakan suatu hasil yang dicapai oleh pekerja dalam pekerjaannya menurut kriteria tertentu yang berlaku untuk suatu pekerjaan (Robbins, 2001). Kinerja pegawai yang tinggi sangatlah diperlukan dalam suatu organisasi untuk mencapai tujuan yang diharapkan. Dengan kinerja yang tinggi pegawai atau karyawan akan berusaha sebaik mungkin untuk mengatasi dan memecahkan masalah yang dihadapi dalam pelaksanaan tugas dan pekerjaannya. Sebaliknya dengan kinerja yang rendah akan mudah menyerah terhadap keadaan apabila mendapatkan kesulitan dalam melaksanakan tugas dan pekerjaannya sehingga akan sulit untuk mencapai tujuan yang diharapkan.

Suatu perusahaan dalam menjalankan kegiatannya selain memperhatikan faktor-faktor yang ada dalam perusahaan juga harus memperhatikan yang ada diluar perusahaan atau yang disebut dengan lingkungan sekitar. Lingkungan sekitar perusahaan yang ada sering disebut kondisi fisik lingkungan kerja. Kondisi lingkungan kerja menyenangkan terlebih lagi bagi semasa jam kerja akan memperbaiki moral pegawai dan kesungguhan kerja, perlatan yang baik, ruangan kerja yang nyaman, perlindungan terhadap bahaya, ventilasi yang baik, karyawan yang cukup, dan keberhasilan bukan saja dapat meningkatkan efisiensi.

Peningkatan kinerja merupakan hal yang mutlak dilakukan oleh manajemen perusahaan demi mencapai tujuan dari perusahaan dan menjaga kelangsungan hidup serta mempertahankan eksistensi perusahaan dalam persaingan bisnis yang ketat sekarang ini.

\section{Rumusan Masalah}


Berdasarkan latar belakang permasalahan yang telah diungkapkan diatas, maka masih diperlukan penelitian yang mengkaji masalah pengaruh hubungan antar manusia, kondisi fisik lingkungan kerja terhadap kinerja pegawai pada suatu perusahaan. Dengan permasalahan yang ada kita harus tau bagaimana hubungan antar manusia dengan kondisi fisik lingkungan yang ada sekarang ini serta dampaknya terhadap kinerja pegawai didalamnya.

\section{Tujuan Penulisan}

Dengan adanya rumusan masalah diatas, tujuan dari artikel ini ialah agar apa yang dilakukan dapat mengarah ke sasaran dan mendapat hasil yang diharapkan, untuk menganalisis pengaruh (human relation) hubungan antar manusia dengan kondisi fisik lingkungan kerja terhadap kinerja pegawai dalam psikologi manajemen.

\section{B. PEMBAHASAN}

\section{Ringkasan Artikel}

\section{a. Hubungan Antar Manusia (Human Relation)}

Hubungan manusiawi adalah terjemahan dari human relation. Orang-orang juga ada yang menterjemahkan menjadi "hubungan manusia" atau juga diterjemahkan "hubungan antar manusia", yang sebenarnya tidak terlalu salah karena yang berhubungan satu sama lain adalah manusia. Hubungan relation karyawan merupakan hubungan manusiawi yang selalu dibutuhkan oleh karyawan, dimana fungsinya sebagai makhluk pribadi dan makhluk sosial, kebutuhan akan orang lain untuk bekerja sama dalam mancapai tujuan hidupnya. Hubungan yang harmonis akan membuat suasana kerja yang menyenangkan dan hala yang mempengaruhi semangat karyawan dalam menjalankan segala pekerjannya.

Dalam (Ermita 2012) human relation (hubungan antar manusia) adalah pemimpin organisasi melakukan komunikasi dengan para karyawan secara manusiawi (human communication) untuk memotivasi 
mereka bekerjasama, sehingga hasilnya baik disamping mereka bekerja dengan hati senang (Onong, 1993:52). Menurut Davis (1989:52), "hubungan antar manusia adalah hubungan atau interaksi antara seseorang dengan orang lain baik dalam situasi kerja atau dalam organisasi".

\section{1) Pengertian Hubungan Antar Manusia}

(Ermita 2012) mengatakan bahwa hubungan antar manusia merupakan salah satu factor yang mempengaruhi semangat kerja pegawai. Adapun yang dimaksud dengan hubungan antar manusia menurut Sarwoto (1991) adalah keseluruhan hubungan baik yang formal maupun informal yang perlu diciptakan dan dibina dalam suatu organisasi sedemikian rupa sehingga tercipta iklim kerja yang intim dan harmonis dalam rangka pencapaian tujuan yang telah ditentukan. Menurut Effendy (1993) menyatakan bahwa hubungan antar manusia pada dasarnya disebut juga dengan istilah human relations, pemberian makna terhadap proses rohaniah yang tertuju kepada kebahagiaan dan kepuasan yang berdasarkan watak, sifat, perilaku, kepribadian, tingkah laku dan lainlain aspek kejiwaan yang terdapat pada diri manusia.

Jadi dapat disimpulkan bahwa hubungan antar manusia adalah kegiatan komunikasi persuasif yang bukan hanya sekedar relasi atau hubungan saja melainkan suatu aktivitas dan suatu kegiatan mengembangkan rasa bahagia dan rasa puas, serta kegiatan untuk meningkatkan dan mengembangkan lebih produktivitas dan memuaskan. Komunikasi persuasif yang dimaksud disini ialah komunikasi yang bersifat membujuk agar tercipta hubungan yang baik.

\section{2) Faktor - Faktor Persepsi Interpersonal Dalam Human Relation}

\section{(Hubungan Antar Manusia)}

(Hamalik, 1993) mengatakan persepsi kita bukanlah sekedar rekaman peristiwa atau objek. Komputer hanya mengolah input yang dimasukkan oleh seseorang. Pengaruh kebutuhan, kesiapan mental, 
suasana emosional, dan latarbelakang budaya, menentukan interpretasi pada sensasi. Apabila objek atau peristiwa di dunia luar kita sebut persepsi maka persepsi tidak selalu sama dengan distal stimuli. Faktor faktor sosial seperti pangaruh interpersonal, nilai- nilai kultural dan harapan - harapan yang dipelajari secara sosial, pada persepsi individu, bukan saja terhadap objek-objek. Persepsi sosial adalah sebagai proses mempersepsi objek - objek dan peristiwa - peristiwa sosial.

\section{3) Hubungan Antara Manusia Dan Situasi Kerja}

Sejalan dengan perkembangan sistem manajemen maka manusia berusaha memperbaiki cara-cara dan alat-alat untuk melaksanakan pekerjaan secara lebih efektif dan lebih mudah. Upaya - upaya yang dilakukan khususnya untuk memperbaiki desain perlengkapan dan metode kerja. Desain perlengkapan berkenaan dengan pertimbangan enginering dan bentuk -bentuk desain yang berguna bagi manusia. Penetapan kebijaksanaan tentang hubungan antara karyawan dalam organisasi dapat dilakukan melalui tiga alternatif pandangan, yakni:

a) Kepentingan organisasi sebagai faktor yang menentukan untuk mencapai maksud - maksud ekonomi, sedangkan karyawan harus menyesuaikan diri terhadap permintaan dan tuntutan organisasi, dan karenanya mereka harus bekerja sama.

b) Membentuk fungsi dan tujuan organisasi dengan cara memenuhi kebutuhan dan minat para karyawan, sehingga terjadi ketergantungan karyawan kepada organisasi.

c) Tanggung jawab manajemen mangacu pada minat karyawan dan organisasi dibangun sehingga karyawan sendiri yang memuaskan kebutuhan dan ambisinya.

Kunci aktivitas human relation adalah motivasi, memotivasikan karyawan untuk bekerja giat berdasarkan kebutuhan mereka secara memuaskan, yakni kebutuhan akan upah yang cukup bagi keperluan 
hidup keluarganya sehari-hari, kebahagiaan keluarganya, kemajuan dirinya sendiri dan lain sebagainya.

Dengan melaksanakan human relation itu pemimpin organisasi atau pemimpin kelompok melakukan komunikasi dengan karyawannya secara manusiawi untuk menggiatkan mereka bekerja sama, sehingga hasilnya memuaskan disamping mereka bekerja sama dengan hati yang gembira. (Mangkunegara, 1993)

\section{b. Kondisi Fisik Lingkungan Kerja}

Menurut (Rukmana 2010) Lingkungan fisik bersifat nyata, lingkungan ini berkenaan dengan kondisi tempat atau ruangan dan kelengkapan material atau peralatan yang diperlukan untuk bekerja. Kondisi yang dimaksud antara lain: kebersihan, penerangan, ventilasi, tata ruang (terutama pengaturan meja, kursi kerja, dan lemari), warna dinding, peralatan kerja yang cukup terpelihara, dan sebagainya. Kondisi ruangan dan peralatan itu akan menimbulkan motivasi kerja yang postif dan modal kerja yang tinggi sehingga tidak mudah menimbulkan kelelahan, tidak mengganggu konsentasi terhadap pekerjaan.

Mengenai lingkungan fisik kerja yang baik, Sarwoto (1991) mengatakan bahwa lingkungan tempat kerja yang dapat mempengaruhi atau meningkatkan efisiensi kerja antara lain : tata ruang kerja yang tepat, cahaya dalam ruangan yang tepat, suhu dan kelembapan udara tepat, suara yang tidak mengganggu konsentrasi kerja.

\section{1) Pengertian Kondisi Fisik Lingkungan Kerja}

Menurut Sarwoto (1991) lingkungan kerja adalah segala sesuatu yang ada disekitar pekerja dan dapat mempengaruhi dirinya dalam menjalankan tugas-tugas yang dibebankan. Kondisi fisik lingkungan ini penting peranannya dalam mencapai tujuan perusahaan karena dengan kondisi fisik lingkungan yang mendukung maka akan membuat karyawan menjadi nyaman dan tenang dalam bekerja, hal ini akan dapat 
mempengaruhi semangat kerja karyawan dalam bekerja, kondisi fisik lingkungan kerja yang baik dapat juga menambah kegairahan kerja serta akan meningkatkan efisiensi. (Rukmana 2010)

Berdasarkan teori diatas dapat diambil kesimpulan bahwa kondisi lingkungan sekitar para karyawan merupakan tempat yang menentukan para karyawan dalam bekerja perlu diciptakan suatu lingkungan yang kondusif yang dapat menentramkan dan dapat membuat betah karyawan dalam bekerja.

2) Faktor Lingkungan Yang Mempengaruhi Lingkungan Kerja Pegawai Antara Lain :

a. Lingkungan kerja non fisik

1) Faktor lingkungan sosial

Lingkungan sosial yang sangat berpengaruh terhadap kinerja karyawan adalah latarbelakang keluarga.

2) Faktor status sosial

Lingkungan sosial yang sangat berpengaruh terhadap kinerja karyawan adalah latarbelakang keluarga yaitu status keluarga, jumlah keluarga, tingkat kesejahteraan dan lain-lain.

3) Faktor hubungan kerja dalam organisasi

Hubungan kerja yang ada dalam organisasi adalah kerja antara karyawan dengan karyawan dan antara karyawan dengan atasan atau pimpinan.

4) Faktor sistem informasi

Hubungan kerja akan dapat berjalan dengan baik apabila ada komunikasi yang baik diantara anggota organisasi atau diantara karyawan perusahaan 
b. Lingkungan kerja fisik

1) Faktor lingkungan tata ruang kerja

Tata ruang kerja yang baik akan mendukung terciptanya hubungan kerja yang baik antara sesama karyawan untuk bertemu.

2) Faktor kebersihan dan kerapian ruang kerja

Ruang kerja yang bersih, rapi, sehat, dan aman akan menimbulkan rasa nyaman dalam bekerja. Hal ini akan meningkatkan gairah dan semangat kerja karyawan dan secara tidak langsung akan meningkatkan kinerja.

\section{c. Kinerja Pegawai}

Menurut (Rukmana 2010) manajemen sumber daya manusia kinerja merupakan hasil yang telah dicapai dari yang telah dilakukan, dikerjakan seseorang dalam melaksanakan kerja atau tugas. Kinerja pegawai adalah hasil dari kerja seseorang karyawan secara keseluruhan selama periode tertentu dalam melaksanakan tugas, seperti standar hasil kerja, target, sasaran atau kinerja yang telah ditentukan terlebih dahulu yang telah disepakati bersama.

\section{1) Pengertian Kinerja}

Menurut (Ermita and Anisah 2013) Kinerja adalah proses kerja untuk mencapai hasil kerja atau prestasi yang diinginkan. Menurut Ruky (2002:15) bahwa : performance atau kinerja adalah catatan tentang hasil-hasil yang diperoleh dari fungsi pekerjaan tertentu atau kegiatan tertentu selama kurun waktu tertentu". seiring dengan itu Wahjosumidjo (2002:22) mengartikan kinerja atau performance adalah sumbangan secara kualitatif maupun kuantitatif yang terukur dalam rangka tercapainya tujuan kelompok dalam suatu unit kerja.Agar kinerja berjalan secara optimal, seseorang harus mempunyai keinginan yang tinggi untuk mengerjakan pekerjaannya serta mengetahui pekerjaannya. 


\section{2) Faktor-faktor yang mempengaruhi kinerja pegawai}

Faktor - faktor yang mempengaruhi kinerja adala sebagai berikut :

a) Faktor individual

Faktor individual ini terdiri dari kemampuan dan keahlian, latarbelakang, demografi, dan motivasi kerja.

b) Faktor psikologis

Faktor psikologis ini terdiri dari: persepdi, attitude, personality, dan pembelajaran.

c) Faktor organisasi

Faktor organisasi ini terdiri dari sistem atau bentuk organisasi sumber daya, kepemimpinan, lingkungan kerja, budaya kerja, budaya organisasi, penghargaan, struktur, diklat dan job design.

\section{d. Pengaruh Hubungan Antar Manusia Dan Kondisi Kerja Lingkungan Terhadap Kinerja Pegawai}

Hubungan antar manusia dalam prestasi kerja pegawai merupakan hubungan kerjasama yang akan membuat antara dua individu atau lebih, khususnya dalam status hubungan kerjasama dalam prsetasi kerja yang dihasilkannya. Baik atau buruknya dapat diukur dengan adanya persaingan diantara pegawai dengan positif dan dapat meningkatkan semangat kerja para pegawai dalam bekerja dan diberikan dengan suatu penghargaan atau penghormatan dan rasa saling tolong menolong dan membantu satu sama lain agar tetap kokoh hubungan atar mereka. Jadi hubungan antar manusia (human relation) berpengaruh positif terhadap hasil kinerja pegawai.

Dan kondisi lingkungan kerja berpengaruh terhadap kinerja pegawai, karena dengan kondisi lingkungan kerja fisik yang baik akan 
menambah produktifitas karyawan tetapi juga dapat meningkatkan efektivitas kerja pegawai atau karyawan tersebut. Dengan adanya peralatan kerja yang baik, ruang kerja yang nyaman, perlindungan terhadap bahaya, ventilasi yang baik, penerangan yang cukup dan kebersihan, bukan saja menambah kegairahab dalam bekerja, tetapi juga dapat meningkatkan prestasi kerja atau kinerja dari para pegawai, sehingga dapat meningkatkan efisiensi kerja pegawai tersebut. Jadi kondisi fisik lingkungan kerja pegawai berpengaruh positif terhadap hasil kinerja pegawai tersebut.

\section{Kajian Analitis}

Dari ringkasan artikel tersebut bahwa teori yang berhubungan dengan human relation, kondisi fisik lingkungan kerja dan kinerja pegawai yaitu dilakukan analisis yaitu pertama pada hubungan antar manusia merupakan unsur dalam manajemen sumber daya manusia yang menciptakan suatu komunikasi diantara sesama manusia dan hal ini akan dapat menimbulkan suatu sikap, pendapat atau perilaku yang saling pengertian didalam melaksanakan pekerjaannya. Kedua kondisi fisik lingkungan kerja ini penting peranannya dalam mencapai tujuan perusahaan karena dengan kondisi fisik lingkungan yang mendukung maka akan membuat karyawan menjadi nyaman dan tenang dalam bekerja, hal ini akan mempengaruhi semangat kerja karyawan dalam bekerja, kondisi fisik lingkungan kerja yang baik dapat juga menambah kegairahan kerja serta meningkatakan efisiensi. Dan ketiga kinerja, kinerja seorang karyawan akan dapat meningkat apabila karyawan itu sadar sepenuhnya akan tugas dan pekerjaannya itu serta memiliki keinginan yang besar untuk menyelesaikan pekerjaannya itu dengan sempurna.

\section{PENUTUP}

\section{Kesimpulan}

Hubungan antar manusia adalah kegiatan komunikasi persuasif yang bukan hanya sekedar relasi atau hubungan saja melainkan suatu aktivitas dan 
suatu kegiatan mengembangkan rasa bahagia dan rasa puas, serta kegiatan untuk meningkatkan dan mengembangkan lebih produktivitas dan memuaskan. Komunikasi persuasif yang dimaksud disini ialah komunikasi yang bersifat membujuk agar tercipta hubungan yang baik.

Kondisi fisik lingkungan kerja karyawan merupakan tempat yang menentukan para karyawan dalam bekerja perlu diciptakan suatu lingkungan yang kondusif yang dapat menentramkan dan dapat membuat betah karyawan dalam bekerja. Kinerja sebagai hasil kerja atau kemampuan yang dapat dicapai oleh seseorang atau sekelompok orang dalam suatu perusahaan sesuai dengan wewenang dan tanggung jawab masing- masing dalam upaya pencapaian tujuan perusahaan secra legal, tidak melanggar hukum dan tidak bertentangan dngan moral dan etika. Jadi kinerja merupakan hasil kerja yang bersifat kualitatif dan kuantitatif.

\section{Saran}

Agar dapat mempertahankan dan meningkatkan kinerja pegawai yang sudah baik atau tinggi, kinerja yang timbul dari dalam diri sendiri merupakan yang paling dalam menjalankan tugasnya, kinerja yang timbul atas dasar kesadaran, kerelaan, keikhlasan, dan bukan atas paksaan ataupun karena ada ambisi yang tidak timbul dari dalam diri sendiri maka hasil kerja yang dicapai tidak akan bertahan lama dan tidak berjalan secara efektif. Agar dapat memotivasi kinerja pegawai yang sudah tinggi menjadi lebih tinggi lagi maka diperlukanlah adanya hubungan antar pegawai dengan pimpinan, hubungan pegawai dengan pegawai dan adanya kondisi fisik lingkungan kerja yang nyaman.dengan demikian diharapkan kepada para pegawai agar tetap bekerja secara solid dan melaksanakan tugasnya dengan baik. 


\section{REFERENSI}

Ermita. 2012. "Hubungan Antar Manusia Dan Semangat Kerja Pegawai." PEDAGOGI, Jurnal Ilmiah Ilmu Pendidikan XII(2): 70-81.

Ermita, and Anisah. 2013. "Pembinaan Dan Kinerja Guru Sekolah Menengah Atas Negeri (Sman).” PEDAGOGI, Jurnal Ilmiah Ilmu Pendidikan XIII(2): 81-92.

Hamalik, O. (1993). Psikologi Manajemen Penuntun Bagi Pemimpin. Jakarta: Trigenda Karya.

Mangkunegara, A. (1993). Psikologi Perusahaan. Bandung: Trigenda Karya.

Rukmana, Widdi Ega. 2010. “Analisis Pengaruh Human Relation (Hubungan Antar Manusia) Dan Kondisi Fisik Lingkungan Terhadap Etos Kerja Dan Kinerja Karyawan Dedy Jaya Plaza Tegal.” Tesis.Universitas Diponegoro: 1146. 